\title{
Effect of Curing Treatments on Seven Key Farmers' Yams (Dioscorea spp.) in Ghana
}

\author{
Charles Tortoe1*, Solomon Dowuona1, Nanam Tay Dziedzoave1, Deborah Rees ${ }^{2}$ \\ ${ }^{1}$ Council for Scientific and Industrial Research-Food Research Institute, Accra, Ghana \\ ${ }^{2}$ Natural Resources Institute, University of Greenwich (Medway Campus), Chatham, UK \\ Email: ${ }^{*}$ ctortoe@yahoo.co.uk
}

Received 6 August 2014; revised 16 September 2014; accepted 16 October 2014

Copyright (C) 2014 by authors and Scientific Research Publishing Inc.

This work is licensed under the Creative Commons Attribution International License (CC BY). http://creativecommons.org/licenses/by/4.0/

(c) (i) Open Access

\section{Abstract}

Curing of freshly harvested yams (Dioscorea spp.) is a process for wounded yams during harvest to heal. In this work the effectiveness of straw, polypropylene and jute sack on curing of seven key farmers' yam varieties over a duration of 7, 14 and 21 days was studied. Seven key farmers' yam varieties identified as Pona, Lariboko, Dente, Mutwumudoo, Serwah belonging to D. rotundata, Matches and Akaba belonging to D. alata were studied under different curing treatments. The percentage weight loss of yam tubers varied among the treatments over curing period. Curing under jute sack showed all yam varieties had weight losses less than $2.0 \%$, within 7 days of curing. Five different varieties had weight loss less than 2.0\% except Dente under the straw treatment. Mutwumudoo variety showed the highest water loss (8.4\%) for polypropylene sheet and $6.9 \%$ for Lariboko in the control treatment. During 7 days curing the control and polypropylene treatment did not support yam curing. After 14 days of curing of tubers, similar tends were observed as in 7 days curing. After 14 days of curing under jute sack, percentage weight loss of the tubers ranges from $2.0 \%-3.7 \%$. In the straw treatment, the percentage weight loss ranges between $1.0 \%-4.7 \%$ in all other varieties except Dente (D. rotundata) $(8.2 \%)$. Polypropylene sheet treatment showed the highest percentage weight loss in Mutwumudoo variety (18.4\%). A similar trend was observed for the yam tubers cured for 21days as percentage weight loss of tubers under jute sacks was 2.5 $9.8 \%$. Curing temperature and humidity ranged between $27^{\circ} \mathrm{C}-40^{\circ} \mathrm{C}$ and $87 \%-100 \%$ rh for yam tubers under the three different treatments of polypropylene, jute and straw. However, the control treatment recorded lower humidity of $60 \%-80 \%$ rh. Curing material, duration, climatic conditions and yam varieties influenced curing and Serwah variety, which is a $D$. rotundata is the best bet yam variety to cure under jute sack for 7,14 and 21 days of curing.

\section{Keywords}

Yam, Dioscorea spp., Curing, Water Loss, Temperature, Humidity, Jute Sack, Grass Straw,

\footnotetext{
"Corresponding author.
}

How to cite this paper: Tortoe, C., Dowuona, S., Dziedzoave, N.T. and Rees, D. (2014) Effect of Curing Treatments on Seven Key Farmers' Yams (Dioscorea spp.) in Ghana. Agricultural Sciences, 5, 1119-1128. 


\section{Polypropylene}

\section{Introduction}

Yams (Dioscorea spp.) are major stable foods in most tropical countries [1]. There are six species that are important staples and these are white yam $(D$. rotundata), water yam $(D$. alata), yellow yam $(D$. cayenensis), trifoliate yam (D. dumetorum), aerial yam (D. bulbifera) and Chinese yam (D. esculenta) [2]. There are about 200 different varieties of yams with fresh colour varying from white, ivory and yellow with long and cylindrical sharps often having offshoots referred to as "toes" while their exterior texture is rough and scaly.

Yams serve as an important source of carbohydrate for many people of the sub-Sahara region, especially in the yam zone of West Africa [3]. According to Ene and Okoli [4] over 50\% of the daily carbohydrate intakes of West Africans are derived from the consumption of yams. It is a high value crop and significant source of dietary energy in Ghana. It provides a good source of vitamin B6, vitamin E, potassium and manganese [5] [6]. They are good sources of carbohydrate and fibres needed for health and vitality. Yams contain a unique fat-like substance called diosgenin, which is technically classified as a hormone-like molecule with probably anti-cancer effects [7] [8].

Ghana is the third largest producer of yams in the world, following Nigeria and Cote d'Ivoire [9] [10]. Yams are utilized all over Ghana and are important in the Ghanaian culture to the extent that yam festival ceremonies are held annually to usher in newly harvested yams in the Northern and Volta regions of Ghana. Yams are cultivated in every region of Ghana by subsistent farmers however it is concentrated largely in the Brong Ahafo and the Northern regions constituting about $37 \%$ and $34 \%$ of the total yam production in Ghana, respectively. Acreage under yam cultivation in 2011 was estimated at 403,798 Ha with corresponding production of approximately 5,855,138 MT with 27,000 MT for export [11]. Per capita consumption of yam in Ghana is estimated at $42 \mathrm{~kg} / \mathrm{annum}$. Interestingly, the high water content of root and tubers influences their low price per unit, and secondly makes transportation difficult with corresponding losses and this includes yam tubers [12] [13].

The increasing demand for yam on the local Ghanaian and international markets requires improvement in its production, storage, transportation and marketing. When yams are being harvested, some tubers are injured in the form of cuts, bruises and abrasions. These openings act as entry points to wound pathogens to attack the yam. According to Booth [14], 15\% of the annual yam production in West Africa alone is lost during storage caused by wound pathogens. In curing, injured yams respond to the injury by forming suberin beneath the expose cells, followed by the formation of periderm (cork) of thickened cells. This acts as a protective barrier against wound pathogens. The process of curing was initially tested on potatoes and sweetpotatoes and was extended to yams by Demeaux and Vivier [15] and Bautista [16]. Curing of sweetpotato roots was reported to improve their storage [15] [17]. Bautista [16] observed that increased temperature and humidity stimulates the yam tubers to form cork cells, which hermetically close the lesions. Thus, cork cells are formed in the cork cambium and transferred into wound areas, which they close with several layers of wound periderm. This layer greatly reduces the desiccation process and prevents infection by bacteria and fungi [18]. According to Bautista [16] in the formation of the wound periderm, metabolic processes take place, which uses energy gained by expiring starch stored in the tuber releasing water, carbon dioxide and heat into the atmosphere. The losses in weight of the tubers during curing depend on the temperature and humidity at the time of curing [16]. FAO [19] reported approximately 1\% loss in fresh weight of tubers at a curing temperature of $35^{\circ} \mathrm{C}-40^{\circ} \mathrm{C}$ and humidity of $80 \%-90 \%$ for duration of 3 days as the curing process allows injured roots and tubers with high water content to heal and protect them from storage diseases and excessive shrinkage [15].

Extensive studies has been done on the physiological processes associated with wound repair in yams during curing but limited information is available pertaining to the effect of different materials on curing of yam tubers. This study investigates the effectiveness of straw, polypropylene and jute sack on curing of the seven key farmers' yam varieties over a cumulative period of 21 days.

\section{Materials and Methods}

\subsection{Materials}

Freshly harvested seven key farmers’ yams (Dioscorea spp.) identified as Pona, Lariboko, Dente, Mutwumudoo, 
Serwah belonging to Dioscorea rotundata, Matches and Akaba belonging to Dioscorea alata were obtained from farm gates at Atebubu in the Atebubu-Amantin District of the Brong Ahafo region in Ghana through the Ministry of Food and Agriculture. The yams were carefully transported to the Pilot Scale Processing Unit of the CSIR-Food Research Institute, where the study was conducted.

Curing materials used were straw, polypropylene and jute sack. The straw was obtained from farmers' fields in Atebubu. The polypropylene and jute sack were purchased from shops in Atebubu.

\subsection{Method}

Freshly harvested mature tubers of each of the seven selected varieties consisting of 84 tubers per variety were used in the study. The tubers were artificially wounded $(4.0 \mathrm{~cm} \times 5.0 \mathrm{~cm})$ using a sharp stainless knife. The wounded tubers were then weighed and the initial weights were recorded. The wounded tubers were arranged in a circular form with the wounded side facing upwards. A temperature/humidity logger was placed on the arranged yams after which it was covered with jute sack. The samples were weighed after curing for 7, 14 and 21 days. The experiment was repeated using polypropylene, straw and a control, which was not covered (Figure 1).

\subsection{Determination of Percentage Water Loss}

In order to account for the initial mass differences of yam tubers, water loss of yam tubers during curing was expressed in g per $\mathrm{g}$ initial mass $(\mathrm{g} / \mathrm{g})$. Percentage water loss $\left(\% \mathrm{WL}_{t}\right)$ is given as:

$$
\% \mathrm{WL}_{t}=\left[\left(W_{i t}-W_{c t}\right) / W_{i t}\right] 100
$$

where $W_{i t}, W_{c t}$ are the initial and final weight of tuber after curing at time $t(t=$ duration in curing treatment).

\subsection{Determination of Curing Temperature and Humidity}

Curing temperature and humidity within each experiment was determined using a Data Logger (Lascar Electronics UK) obtained from Natural Resources Institute, United Kingdom. The data recorded was then analyzed using Data Logging Software Version 5.51 (EasyLog).

\subsection{Statistical Analysis}

Analyses were carried out in triplicates and data expressed as means \pm standard deviation. Analysis of variance was performed and Duncan multiple test range was used to separate means using the Statgraphics Centurion 16.1.11 (StatPoint Technologies Inc, USA, 2010). Comparisons between sample treatments and correlation analysis were done with a probability $p=0.05$.

\section{Results}

\subsection{Percentage Weight Loss of Cured Yam Tubers}

In studies reported by Been et al. [20], Demeaux and Vivier [15] and FAO [19] there are various process of wound healing, which is influenced by technical methods, temperature and humidity of the environment and duration of treatment. Similar observations were made in this study. After 7 days of curing the percentage weight loss of yam tubers varied among the treatments. Curing under the jute sack showed all yam varieties weight loss less than $2.0 \%$. Under the straw treatment, five varieties weight loss were less than $2.0 \%$ except Dente. The highest water loss (8.4\%) occurred in the polypropylene sheet for Mutwumudoo and $6.9 \%$ for Lariboko in the control treatment (Figure 2). The control and polypropylene sheet did not support yam curing within 7 days of curing. The best curing for 7 days was observed for jute sack and straw treatment for Serwah (0.9\%), $a$ Dioscorea rotundata and Matches (0.2\%), a Dioscorea alata, respectively.

After 14 days of curing of tubers, similar tends were observed for tubers cured for 7 days. In the jute sack, percentage weight loss of the tubers ranges from $2.0 \%-3.7 \%$. Only Lariboko variety was $8.4 \%$. In the straw treatment, the percentage weight loss was between $1.0 \%-4.7 \%$ for all other varieties except Dente (Dioscorea rotundata) (8.2\%). Polypropylene sheet treatment showed the highest percentage weight loss in Mutwumudoo variety (18.4\%). Percentage weight loss of the other varieties ranges from $1.5 \%-4.9 \%$. In control treatments, 

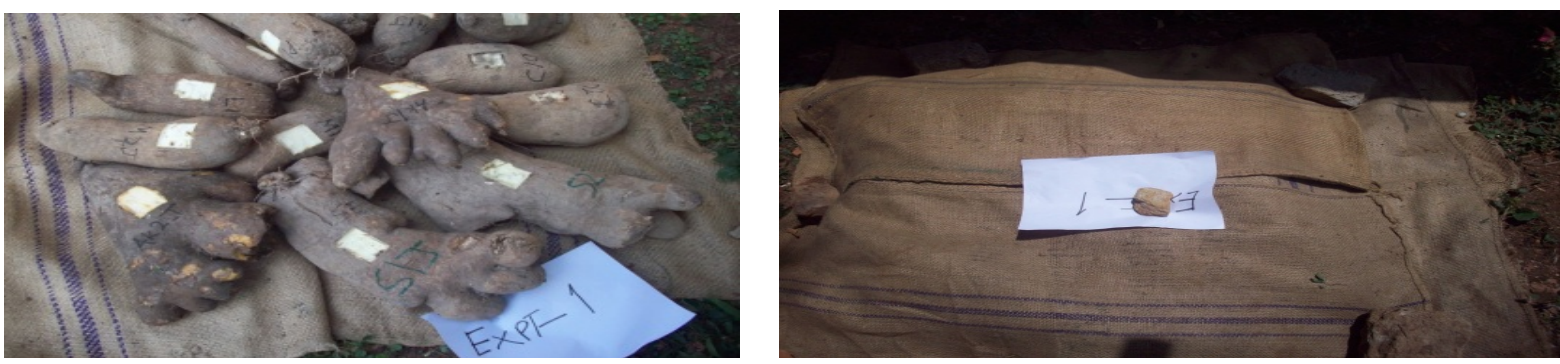

(a)
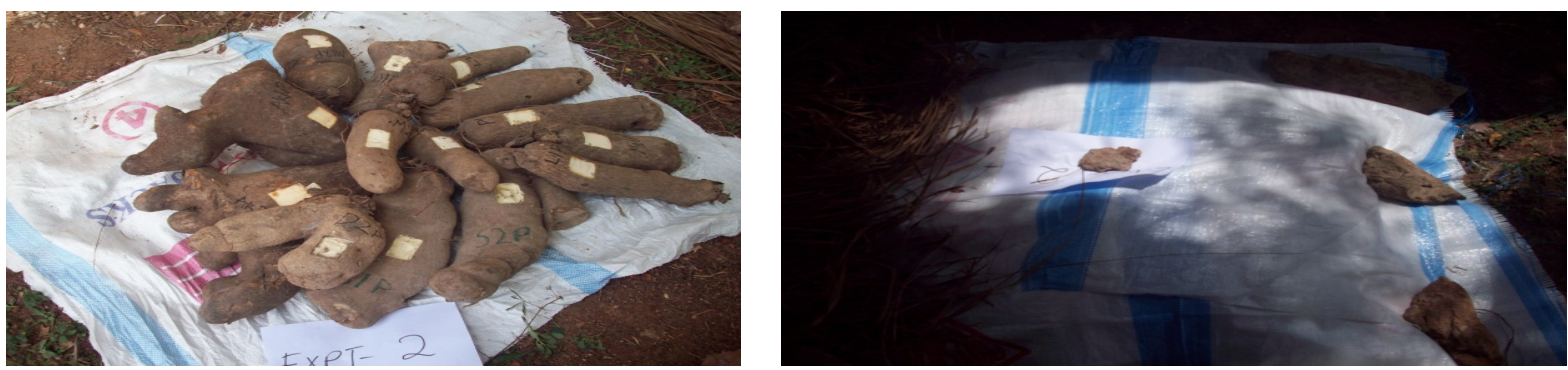

(b)
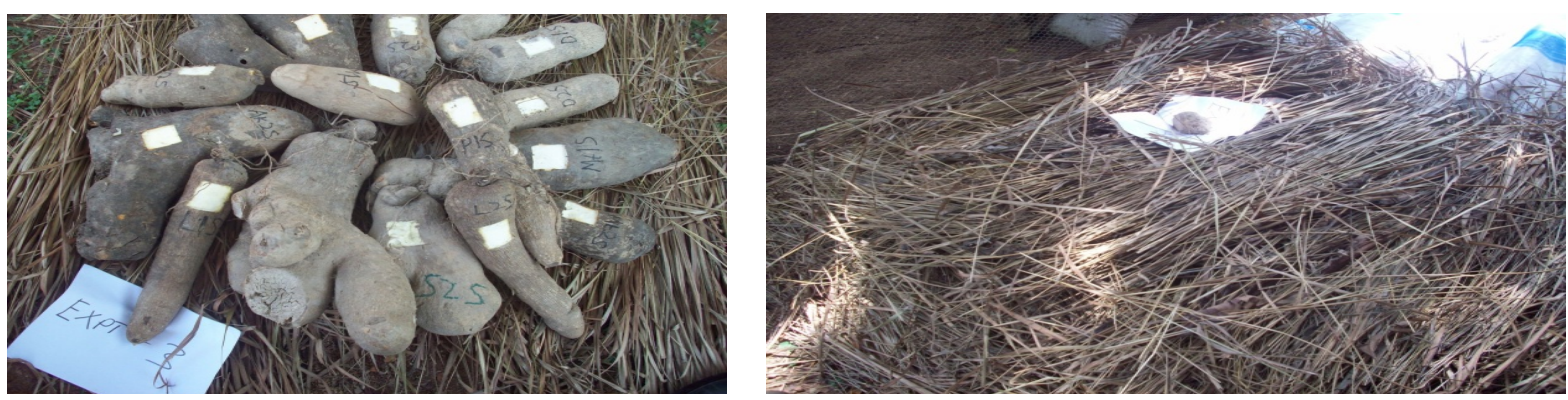

(c)
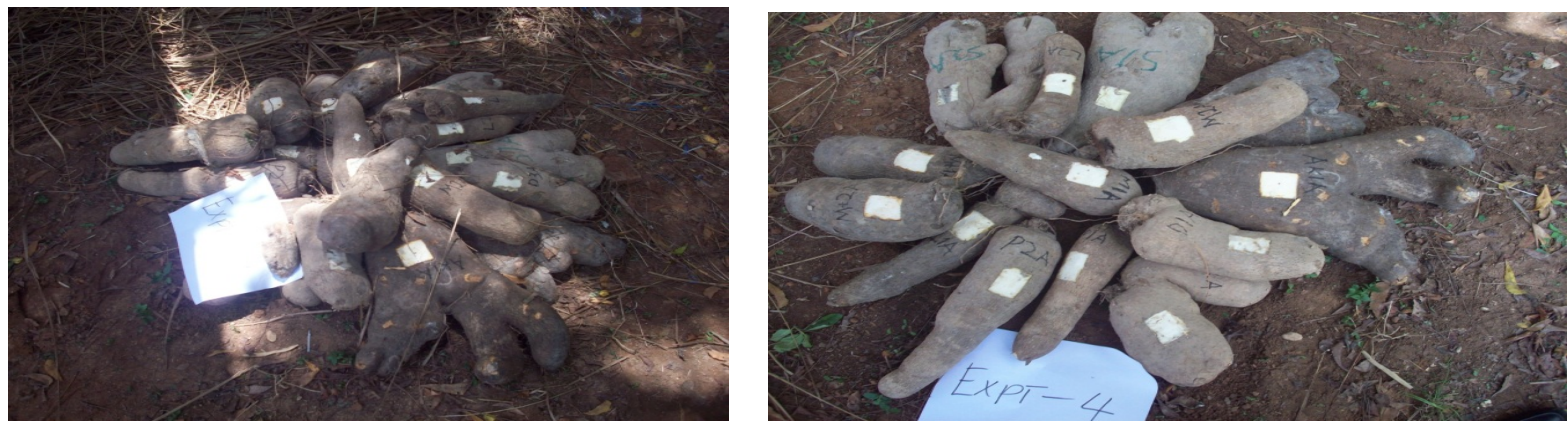

(d)

Figure 1. Curing of yam under different conditions. (a) Wounded tubers and covered with jute sack for curing; (b) Wounded tubers and covered with polypropylene sack for curing; (c) Wounded tubers and covered with straw for curing; (d) Wounded tubers and uncovered as control for curing.

percentage weight loss ranges between 1.3 - 13.9\%. It recorded the highest percentage water loss of $13.9 \%$ in Lariboko variety (Figure 3).

A similar trend was observed for the yam tubers under curing after 21days of curing as percentage weight loss of tubers under jute sacks was $2.5 \%-9.8 \%$. Percentage water loss of tubers curing under straw ranges between $2.2 \%-10.7 \%$. The highest percentage was $21.6 \%$ observed in Mutwumudoo under polypropylene sheets. The percentage weight loss (17.0\%) of Lariboko variety was the highest among the tubers under control treatment. In the remaining varieties the percentage water loss was $2.2 \%$ - 5.7\% (Figure 4). The percentage water loss from 


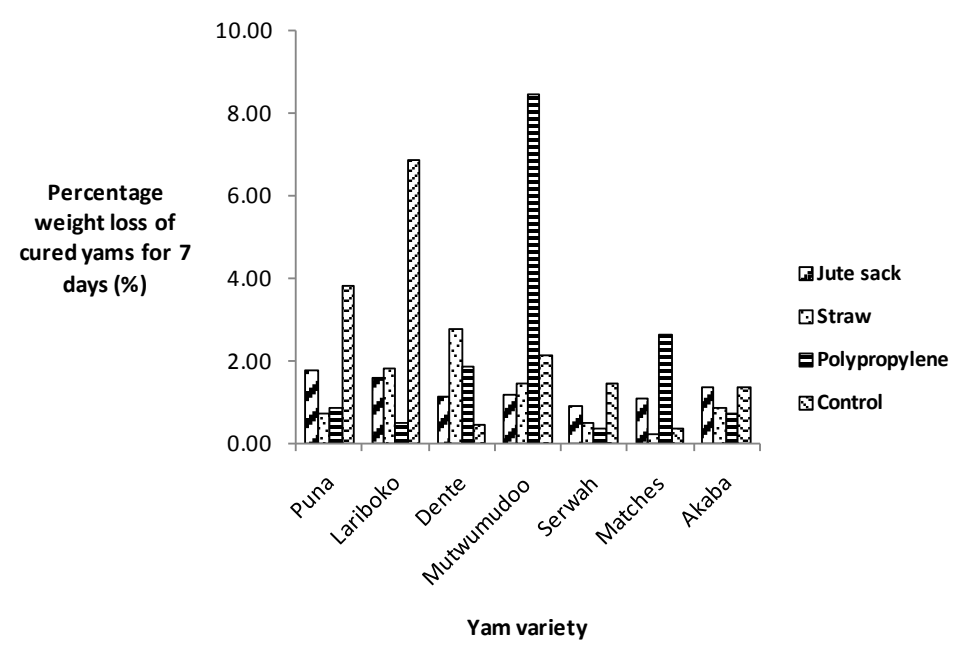

Figure 2. Percentage weight lost after 7 days of curing.

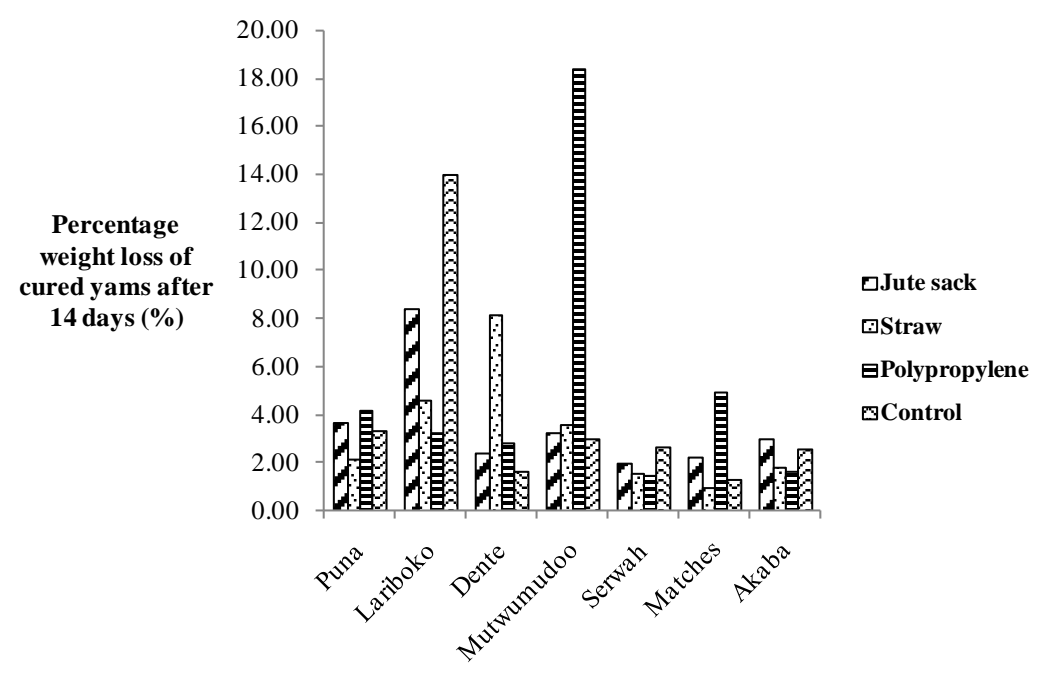

Figure 3. Percentage weight lost after 14 days of curing.

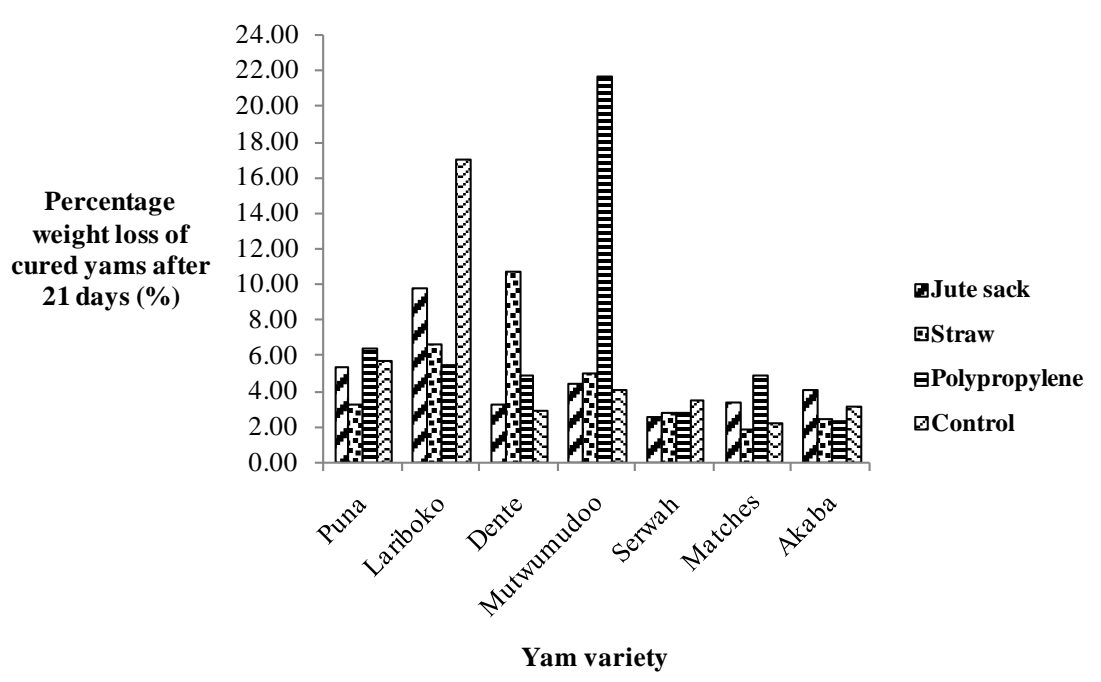

Figure 4. Weight lost during 21 days of curing. 
the cured yam tubers is an indication that healing of wounds is related to a certain loss in tuber weight as reported by Bautista [16]. The loss in weight is influenced by the curing conditions implemented. In curing studies conducted on yams in a combination of straw and jute sheets showed weight losses of approximately $1 \%$ of the fresh weight of the tubers for 3 days duration [19]. Interestingly, when yam tubers are deeply injured they undergo a process of wound repair which is made up of migration of starch cells to the injured surface within 5 10 hours of injury. This is followed by the formation of a suberized layer beneath the cut surface after $2-3$ days and the production of periderm (cork) after approximately 5 days. There is increased rate of respiration as well as increased hydrolysis of starch to sugars by invertase activity during the changes. Interestingly, studies by Jenkins [21] shows that respiratory losses are higher and greater under tropical temperatures. The increased rate of metabolic activity is maintained until healing is complete. However, wound healing processes do not occur when tubers are injured by surface abrasions or severe bruising. When such abrasions or superficial cuts occur on yams they undergo increased respiratory activity and weight loss until decay as they are exposed to prolong loss of moisture and an increased susceptibility to rot pathogens [22]. Other authors have described wound healing during curing as a process of lignification as cell walls below the wounded cell layers become thickened with lignin or suberin [23] [24].

Statistical analysis of the mean weight loss of the tubers at curing for the four treatments is presented in Tables 1-3. After 7 days of curing under the different conditions, mean weight loss of the seven yam varieties differed significantly $(p=0.05)$. Curing under jute sack, the mean weight loss ranged between $0.009-0.12$ for Mutwumudoo and Serwah as the lowest and Mutwumudoo as the highest yam varieties. Serwah variety recorded the smallest mean weight loss during 7 days curing period under polypropylene sheet and control. However, other varieties behaved quite differently. While Mutwumudoo cured well under jute sack, it did not perform well under polypropylene. A similar trend was observed under straw, which shows that Matches performed well than the other varieties. Curing under polypropylene and control treatment shows Mutwumudoo losing weight more than the other varieties.

Similar trends were observed under the influence of curing treatment and duration of 14 and 21 days. After curing cumulatively for 14 and 21 days Serwah, Matches and Akaba cured appropriately under jute sack and straw than polypropylene and control treatments (Table 2, Table 3).

Table 1. Weight loss of yams after 7 days curing.

\begin{tabular}{|c|c|c|c|c|}
\hline Yam variety & Jute sack & Polypropylene sheet & Straw & Control \\
\hline Pona & $0.018 \pm 0.012 \mathrm{a}$ & $0.008 \pm 0.008 a$ & $0.007 \pm 0.007 a$ & $0.038 \pm 0.038 a$ \\
\hline Lariboko & $0.016 \pm 0.005 a$ & $0.005 \pm 0.005 a$ & $0.018 \pm 0.014 \mathrm{a}$ & $0.069 \pm 0.058 \mathrm{a}$ \\
\hline Dente & $0.011 \pm 0.007 a$ & $0.019 \pm 0.059 a$ & $0.027 \pm 0.027 a$ & $0.004 \pm 0.004 a$ \\
\hline Mutwumudoo & $0.012 \pm 0.001 \mathrm{a}$ & $0.084 \pm 0.084 a$ & $0.015 \pm 0.015 a$ & $0.021 \pm 0.012 \mathrm{a}$ \\
\hline Serwah & $\mathbf{0 . 0 0 9} \pm 0.009 a$ & $\mathbf{0 . 0 0 3} \pm 0.003 \mathrm{a}$ & $0.005 \pm 0.004 a$ & $0.014 \pm 0.011 \mathrm{a}$ \\
\hline Matches & $0.011 \pm 0.009 a$ & $0.026 \pm 0.006 a$ & $\mathbf{0 . 0 0 2} \pm 0.002 \mathrm{a}$ & $\mathbf{0 . 0 0 3} \pm 0.003 a$ \\
\hline Akaba & $0.013 \pm 0.010 \mathrm{a}$ & $0.007 \pm 0.007 a$ & $0.008 \pm 0.008 a$ & $0.014 \pm 0.014 a$ \\
\hline
\end{tabular}

Means in column followed by the same letter are not significantly different $(p=0.05)$ from each other.

Table 2. Weight loss of yams after 14 days curing.

\begin{tabular}{ccccc}
\hline Yam variety & Jute sack & Polypropylene sheet & Straw & Control \\
\hline Pona & $0.037 \pm 0.012^{\mathrm{a}}$ & $0.042 \pm 0.028^{\mathrm{a}}$ & $0.021 \pm 0.010^{\mathrm{a}}$ & $0.033 \pm 0.019^{\mathrm{a}}$ \\
Lariboko & $0.084 \pm 0.055^{\mathrm{a}}$ & $0.033 \pm 0.017^{\mathrm{a}}$ & $0.047 \pm 0.016^{\mathrm{ab}}$ & $0.139 \pm 0.042^{\mathrm{b}}$ \\
Dente & $0.025 \pm 0.008^{\mathrm{a}}$ & $0.029 \pm 0.007^{\mathrm{a}}$ & $0.082 \pm 0.030^{\mathrm{b}}$ & $0.017 \pm 0.007^{\mathrm{a}}$ \\
Mutwumudoo & $0.032 \pm 0.011^{\mathrm{a}}$ & $0.184 \pm 0.059^{\mathrm{b}}$ & $0.037 \pm 0.013^{\mathrm{a}}$ & $0.030 \pm 0.009^{\mathrm{a}}$ \\
Serwah & $\mathbf{0 . 0 2 0} \pm 0.011^{\mathrm{a}}$ & $\mathbf{0 . 0 1 5} \pm 0.006^{\mathrm{a}}$ & $0.016 \pm 0.007^{\mathrm{a}}$ & $0.027 \pm 0.008^{\mathrm{a}}$ \\
Matches & $0.023 \pm 0.007^{\mathrm{a}}$ & $0.049 \pm 0.017^{\mathrm{a}}$ & $\mathbf{0 . 0 1 0} \pm 0.005^{\mathrm{a}}$ & ${\mathbf{0 . 0 1 3} \pm 0.006^{\mathrm{a}}}_{0.026 \pm 0.008^{\mathrm{a}}}$ \\
Akaba & $0.030 \pm 0.009^{\mathrm{a}}$ & $0.017 \pm 0.006^{\mathrm{a}}$ & $0.018 \pm 0.006^{\mathrm{a}}$ & 0.026
\end{tabular}

Means in column followed by the same letter are not significantly different $(p=0.05)$ from each other. 


\subsection{Temperature and Relative Humidity}

The temperature and humidity over 7, 14 and 21 days of curing is presented in Figures 5-7. Curing of yam tubers under the three different treatments showed temperature and humidity in the range of $27^{\circ} \mathrm{C}-40^{\circ} \mathrm{C}$ and $87 \%$

Table 3. Weight loss of yams after 21 days curing.

\begin{tabular}{ccccc}
\hline Yam variety & Jute sack & Polypropylene sheet & Straw & Control \\
\hline Pona & $0.054 \pm 0.014^{\mathrm{a}}$ & $0.063 \pm 0.027^{\mathrm{a}}$ & $0.033 \pm 0.011^{\mathrm{ab}}$ & $0.057 \pm 0.024^{\mathrm{a}}$ \\
Lariboko & $0.098 \pm 0.042^{\mathrm{a}}$ & $0.054 \pm 0.019^{\mathrm{a}}$ & $0.066 \pm 0.018^{\mathrm{bc}}$ & $0.170 \pm 0.036^{\mathrm{b}}$ \\
Dente & $0.033 \pm 0.008^{\mathrm{a}}$ & $0.049 \pm 0.016^{\mathrm{a}}$ & $0.107 \pm 0.027^{\mathrm{c}}$ & $0.029 \pm 0.010^{\mathrm{a}}$ \\
Mutwumudoo & $0.044 \pm 0.011^{\mathrm{a}}$ & $0.216 \pm 0.048^{\mathrm{b}}$ & $0.050 \pm 0.013^{\mathrm{ab}}$ & $0.040 \pm 0.010^{\mathrm{a}}$ \\
Serwah & $\mathbf{0 . 0 2 5} \pm 0.006^{\mathrm{a}}$ & $0.028 \pm 0.011^{\mathrm{a}}$ & $0.028 \pm 0.009^{\mathrm{ab}}$ & $0.035 \pm 0.008^{\mathrm{a}}$ \\
Matches & $0.033 \pm 0.009^{\mathrm{a}}$ & $0.049 \pm 0.012^{\mathrm{a}}$ & $\mathbf{0 . 0 1 8} \pm 0.006^{\mathrm{a}}$ & $\mathbf{0 . 0 2 2}^{\mathrm{a}}$ \\
Akaba & $0.041 \pm 0.010^{\mathrm{a}}$ & $\mathbf{0 . 0 2 4} \pm 0.006^{\mathrm{a}}$ & $0.025 \pm 0.006^{\mathrm{ab}}$ & $0.031 \pm 0.007^{\mathrm{a}}$ \\
\hline
\end{tabular}

Means in column followed by the same letter are not significantly different $(p=0.05)$ from each other.

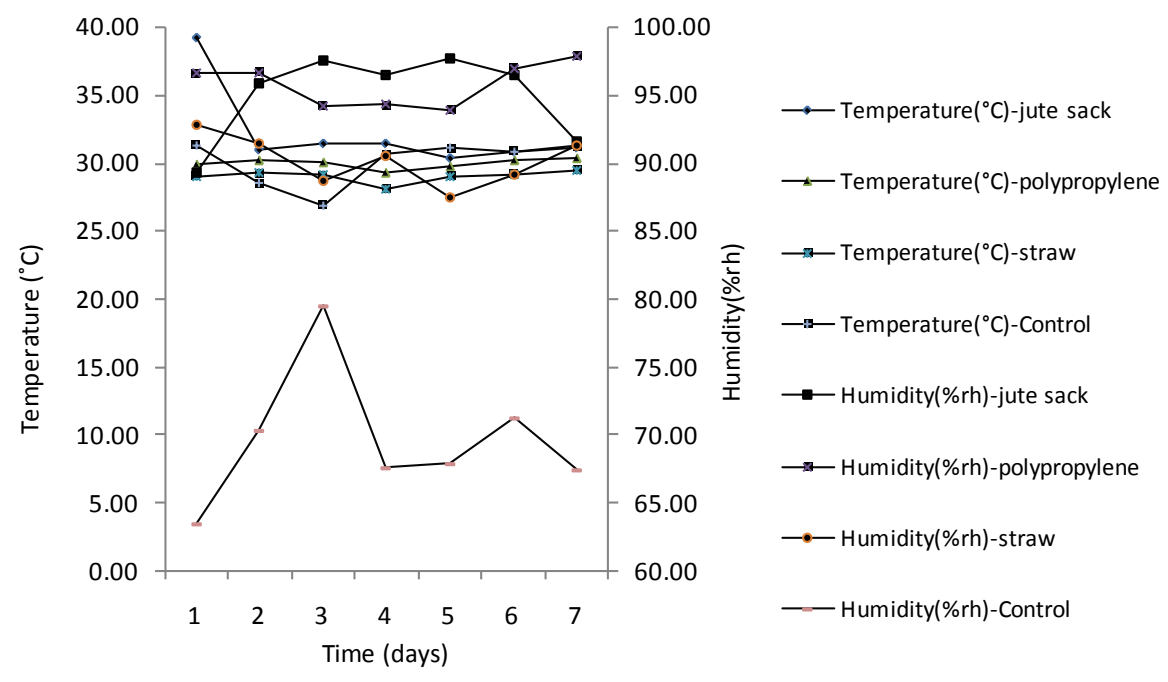

Figure 5. Temperature and humidity changes during the first 7 days.

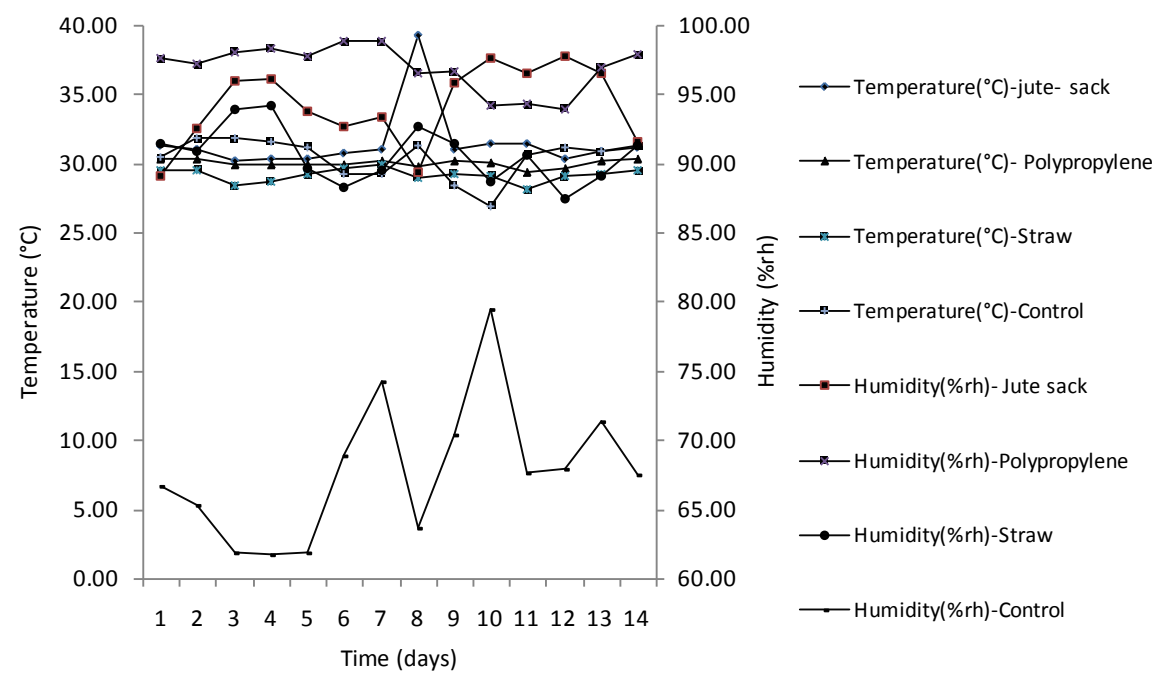

Figure 6. Temperature and humidity changes during 14 days of curing. 


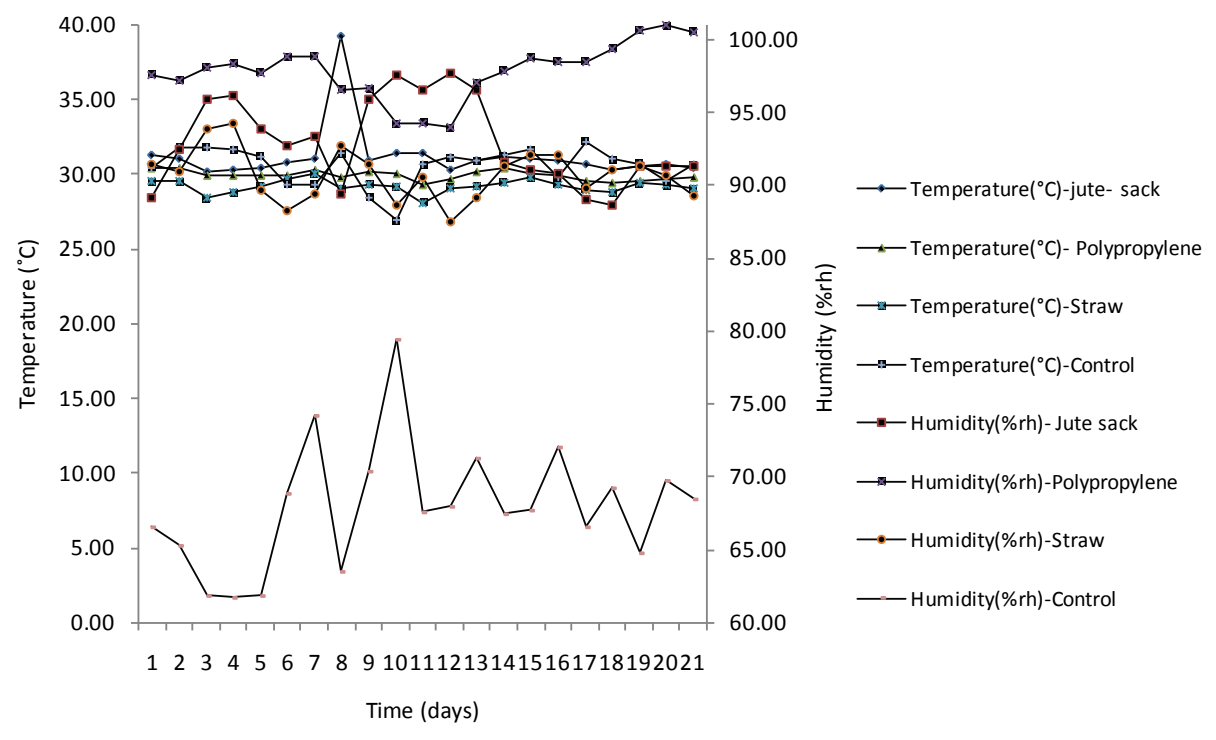

Figure 7. Temperature and humidity changes during 21 days of curing.

- $100 \%$ rh, respectively. However, the control treatment recorded lower humidity of $60 \%-80 \%$ rh (Figures 5-7). These ranges are similar to $35^{\circ} \mathrm{C}-40^{\circ} \mathrm{C}$ and $80 \%-90 \%$ for temperature and humidity as reported by FAO (1990). In other studies the best temperature and humidity was $26^{\circ} \mathrm{C}$ and $92 \%$, respectively for duration of 11 to 15 days in pit curing system [25]. These values are similar to that obtained in this study. In similar studies on curing of sweetpotatoes, the roots cure efficiently when roots were exposed to temperatures of $28^{\circ} \mathrm{C}-30^{\circ} \mathrm{C}$ and relative humidity (RH) greater than $85 \%$ that aids the formation of a layer of cork cells around the roots [26]. In other studies at similar temperature and humidity, the percentage weight loss during storage of cured and uncured roots in the West Indies for 113 days was $17 \%$ and 43\%, respectively [17].

Similar curing studies on sweetpotatoes were reported by Tortoe et al. [27], where the roots initially cured under temperature $\left(30^{\circ} \mathrm{C}-35^{\circ} \mathrm{C}\right)$ and humidity $(90 \%-95 \% \mathrm{rh})$ conditions for 7 and 14 days and subsequently stored in local (traditional), pit and clamp storage structures for 84 days. Earlier studies on sweet potatoes were reported by Rees et al. [28].

Climatic conditions have influences on curing as increase temperature and humidity stimulate the healing process. The healing process during curing causes migration of starch cells within 5 - 10 hours to the injured surface. Suberized layer forms beneath the cut surface after 2 - 3 days and there is production of periderm (cork) after approximately 5 days during healing. The increased structural changes results in high rate of metabolic activity which is maintained until healing is completed [21] [29] [30].

\section{Conclusion}

The process of curing is affected by the curing material, duration of curing, climatic conditions and the varieties of yams. The varieties of the yams behaved differently under the different treatments. However, yam variety Serwah, which is a $D$. rotundata, is the best bet yam variety to cure under jute sack for 7,14 and 21 days of curing. However, 7 days curing was appropriate for yams. Additionally, the second best bet yam variety curing under straw was Matches, which is a D. alata. Curing processing is therefore appropriate for wounded yams to cure for storage.

\section{Acknowledgement}

The authors are grateful for sponsorship from Grains from Losses of Root and Tubers Crops Project (GRATITUDE Project).

\section{References}

[1] Akanbi, C.T., Gureje, P.O. and Adeyemi, I.A. (1996) Effect of Heat-Moisture Pre-Treatment on Physical Characteris- 
tics of Dehydrated Yam. Journal of Food Engineering, 28, 45-48. http://dx.doi.org/10.1016/0260-8774(95)00027-5

[2] Ng, N.Q. and Ng, S.Y.C. (1994) Approaches for Yam Germplasm Conservation. Proceeding of the 5th Triennial Symposium of the International Society for Tropical Root Crops-Africa, Kampala, 22-24 November 1992, 135-140.

[3] Akissoe, N., Hounhonigan, J., Mestres, C. and Nago, M. (2003) How Blanching and Drying Affect the Colour and Functional Characteristics of Yam (Dioscorea cayenensis-rotundata) Flour. Food Chemistry, 82, 257-264. http://dx.doi.org/10.1016/S0308-8146(02)00546-0

[4] Ene, L.S.O. and Okoli, O.O. (1985) Yam Improvement: Genetic Considerations and Problems. In: Osuji, G.O., Ed., Advances in Yam Research, Anambra State University of Technology, Enugu, 343-360.

[5] Food and Agriculture Organization (FAO) (1985) Production Year Book 38. FAO, Rome, Italy.

[6] Food and Agriculture Organization (1987) Dossier. Root and Tubers, Their Role in Food Security. The Courier No. 101. FAO, Rome, 62-65.

[7] Green, K.R. and Simons, S.A. (1994) “Dead Skin” on Yams Dioscorea alata Caused by Colletotrichum gloeosporioides. Plant Pathology, 43, 1062-1065. http://dx.doi.org/10.1111/j.1365-3059.1994.tb01660.x

[8] Mishra, D., Mishra, A.B. and Ruth, G.C. (1989) Fungal Rots of Colocasia, Yam Beet and Carrot in Orissa Markets. Orissa Journal of Agriculture Research, 2, 156-159.

[9] MEDA (2011) Ghana Yam Market, Sub-Sector and Value Chain Assessment. Final Report for The Bill \& Melinda Gates Foundation, 13th May 2011.

[10] MoFA (2012) Statistics, Research and Information Directorate (SRID). Ministry of Food and Agriculture, Accra.

[11] Food and Agriculture Organization (FAO) (2012) Statistics of the Food and Agriculture Organization of the United Nations.

[12] Hahn, N.D. (1989) The African Farmer and Her Husband. In: Deutsche Stiftung Fur international Entwicklung (Dse) (Edi.): Roots Tubers and Legumes, Report of the Expert Meeting, Bonn, 71-93.

[13] Lynam, J.K. (1991) The Development Potential of Root Crops in Africa. Entwicklung und Ländlicher Raum, 1, 8-12.

[14] Booth, R.H. (1974) Post-Harvest Deterioration of Tropical Root Crops: Losses and Control. Tropical Science, 16, 4963.

[15] Demeaux, M. and Vivier, P. (1984) Methodes moderns de conservation des ignames. L'Agronomie Tropicale, 39, 184191.

[16] Bautista, O.K. (1990) Postharvest Technology for Southeast Asian Perishable Crops. University of the Philippines, Los Banos.

[17] Thompson, J. (1972) Storage and Transport of Fruit and Vegetables in the West Indies. Proceedings of the Seminar /Workshop on Horticultural Development in the Caribbean, Matarin, 12-15 March 1972, 170-176.

[18] Hayma, J. (1982) The Storage of Tropical Agriculture Products. Agrodok 31. ACP/EEC, Wageningen, 73 p.

[19] FAO (1990) Action Programme for the Prevention of Food Losses, Improving Post-Harvest Handling, Storage and Processing of Root and Tuber Crops. Food and Agriculture Organization, Rome.

[20] Been, et al. (1977) Yam Curing for Storage. Acta Horticulturae, 62, 311-316.

[21] Jenkins, P.D. (1982) Losses in Sweet Potato Stored under Local Conditions in Bangladesh. Tropical Science, 24, 1728.

[22] Passam, H.C., Read, S.J. and Rickard, J.E. (1976) Wound Repair in Yam Tubers: Physiological Processes during Repair. New Phytology, 77, 325-331. http://dx.doi.org/10.1111/j.1469-8137.1976.tb01522.x

[23] Walter, W.M. and Schadel, W.E. (1982) A Rapid Method of Evaluating Curing Progress in Sweet Potatoes. Journal of the American Society for Horticultural Science, 107, 1129-1133.

[24] Walter, W.M. and Schadel, W.E. (1983) Structure and Composition of Normal Skin (Periderm) and Wound Tissue in Sweet Potatoes. Journal of the American Society for Horticultural Science, 108, 909-914.

[25] Nnodu, E.C. (1987) Pit-Curing Technique for Prolonging the Shelf Life of Yam Tubers. In: Terry, E.R., Ed., Tropical Root Crops, Root Crops and the African Food Crisis, Nigeria, 140-142.

[26] Kushman, L.J. and Wright, F.S. (1969) Sweet Potato Storage. USDA Agriculture Handbook No. 358, 44 p.

[27] Tortoe, C., Obodai, M., Amoa-Awua, W., Oduro-Yeboah, C. and Vowotor, K. (2008) Effectiveness of Three Different Storage Structures and Curing Process for the Storage of Sweet Potato (Ipomea batatas) in Ghana. Ghana Journal of Agriculture Science, 41, 227-236.

[28] Rees, D., Van Oirschot, Q.E.A. and Kapinga, A. (2003) Sweet Potato Post-Harvest Assessment: Experiences from East Africa. Natural Resources Institute, Chatham, $122 \mathrm{p}$. 
[29] Passam, H.C. (1977) Sprouting and Apical Dominance of Yam Tubers. Tropical Science, 19, 29-39.

[30] Passam, H.C., Read, S.J. and Rickard, J.E. (1978) The Respiration of Yam Tubers and Its Contribution to Storage Losses. Tropical Agriculture Trinidad, 55, 207-213. 
Scientific Research Publishing (SCIRP) is one of the largest Open Access journal publishers. It is currently publishing more than 200 open access, online, peer-reviewed journals covering a wide range of academic disciplines. SCIRP serves the worldwide academic communities and contributes to the progress and application of science with its publication.

Other selected journals from SCIRP are listed as below. Submit your manuscript to us via either submit@scirp.org or Online Submission Portal.
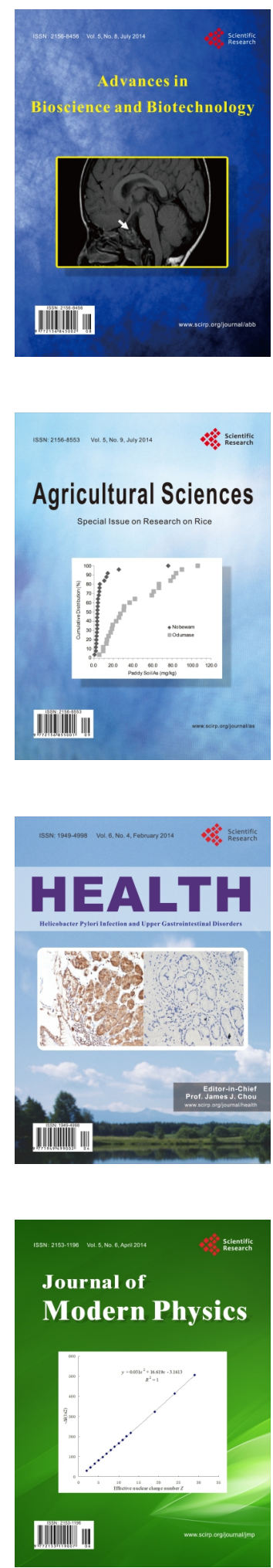
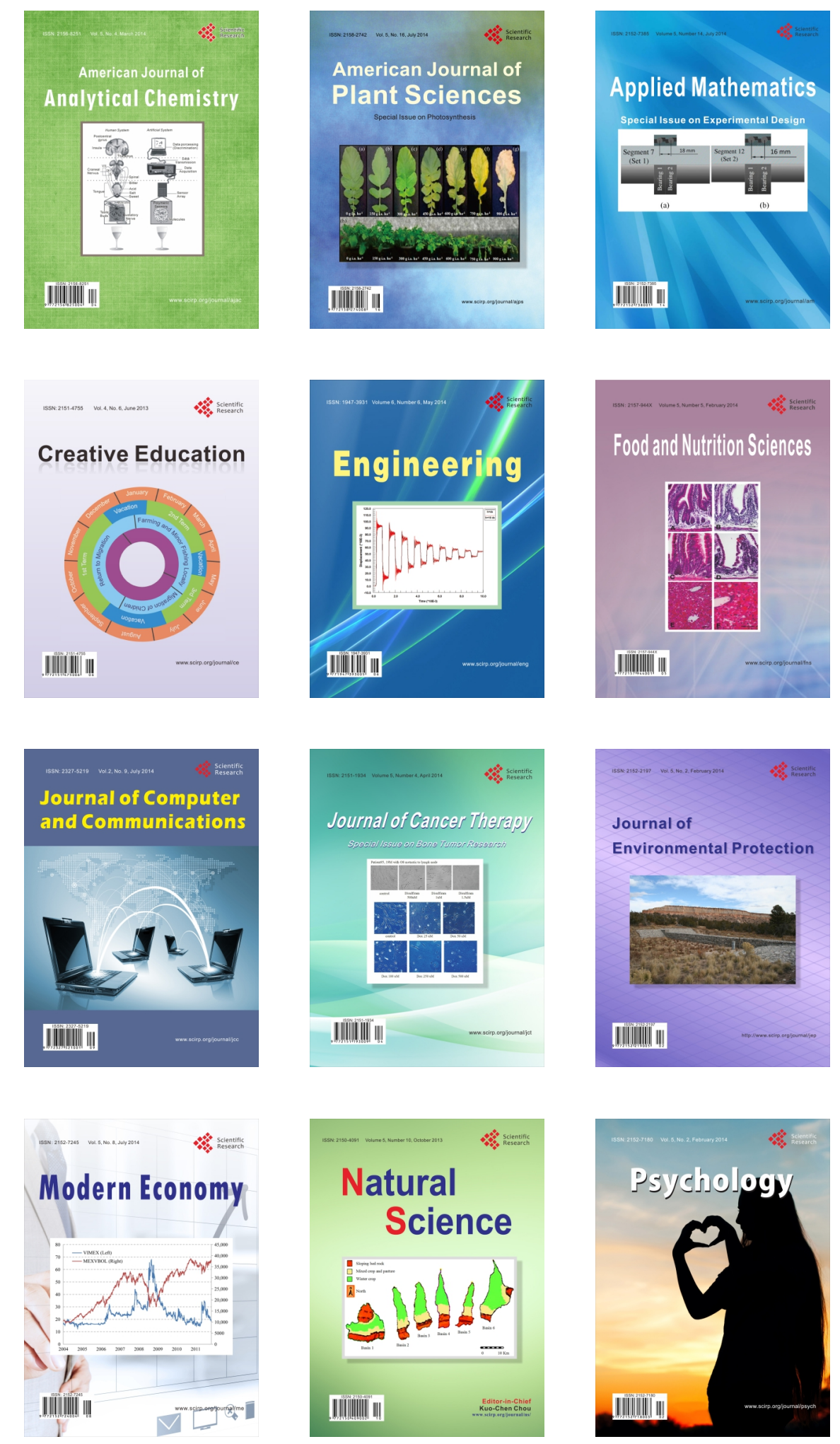